\title{
Uso do extrato de papaína a $5 \%$ na cicatrização de ferida cutânea em equino - relato de caso
}

Suyan Brethel dos Santos Campos $^{[a]}{ }^{*}$, Ana Karolina Camargo $0^{[a]}$, Paulo Ricardo Pereira Almeida de Oliveira[b], Thaís de Lima Felipe $^{[c]}$, Victoria Dias Carlos dos Santos ${ }^{[c]}$, Roberta Lourrana Gonçalves Cardoso $0^{[c]}$, Gabriella Silva Campos ${ }^{[d]}$

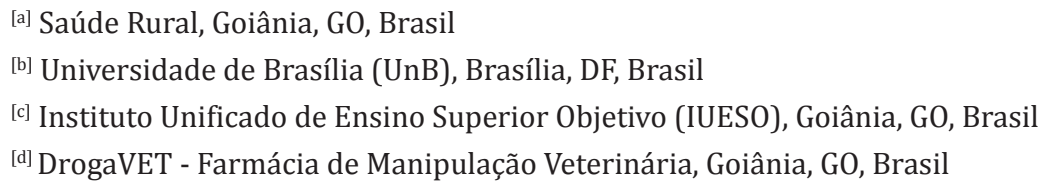

${ }^{*}$ Autor correspondente

e-mail: sauderuralvet@gmail.com

\section{Resumo}

0 tratamento de feridas cutâneas é uma rotina na clínica de veterinários que trabalham com equinos. Em geral, a cicatrização de feridas apresenta um prognóstico favorável, porém existem algumas particularidades que podem tornar esse processo complicado e demorado. Existem disponíveis diversas formulações alopáticas para o tratamento das feridas, porém estas podem contribuir para o retardo na contração da ferida, epitelização e reparação tecidual. 0 uso de fitoterápicos como a papaína, que é uma enzima de origem vegetal extraída do látex do mamão (Carica papaya), vem sendo utilizada para o auxílio nos processos de cicatrização tecidual em função do seu poder bactericida, bacteriostático e debridante seletivo de tecidos necrosados, desvitalizados e infectados. 0 objetivo deste trabalho é relatar um caso de cicatrização de ferida cutânea em um equino tratado com o uso de pomada à base de extrato de papaína a 5\%, atendido na clínica Saúde Rural, localizada na cidade de Goiânia. Foi atendido no dia 16/02/2017 um equino da raça Quarto de Milha, fêmea, 1 ano de idade. 0 animal apresentava laceração na região do peitoral, que media, aproximadamente, $9 \mathrm{~cm} \times 6 \mathrm{c} \mathrm{m}$, com a ruptura parcial das fibras do músculo peitoral descendente. 0 tempo percorrido entre o acidente na propriedade e a chegada à clínica foi de 10 horas. Realizou-se a sedação com detomidina na dose de $20 \mu \mathrm{g} / \mathrm{Kg}$ via EV, bloqueio loco-regional com lidocaína $2 \%$ e síntese da ferida com fio de nylon no 0 em padrão Wolff captonado. Foram administrados enrofloxacina por via oral na dose de $5 \mathrm{mg} / \mathrm{kg}$, uma vez ao dia, durante sete dias, soro antitetânico por via IM em dose única, e fenilbutazona por via $\mathrm{EV}$ na dose de $4,4 \mathrm{mg} / \mathrm{kg}$, uma vez ao dia, durante três dias. 0 curativo da ferida era feito diariamente, com uso de clorexidina tópica e aplicação de spray repelente. Após cinco dias ocorreu deiscência da ferida 
e foi observada a presença de secreção purulenta. Foram retirados os pontos e os bordos reavivados para que a cicatrização ocorresse por segunda intenção. Iniciou-se a aplicação da pomada manipulada à base de extrato de papaína a 5\% (Drogavet, Goiânia, GO) após a limpeza da ferida com solução fisiológica, uma vez ao dia. A pomada era conservada sob refrigeração. Após o estabelecimento do tratamento com o uso da pomada fitoterápica, observou-se a ausência de secreção, o que dispensou a continuidade do tratamento com antibiótico sistêmico. A retração dos bordos da ferida seguiu de maneira concêntrica, sem a formação de tecido de granulação. A cicatrização completa da ferida foi observada sete dias após o início do tratamento. Apesar da realização da sutura na região peitoral, o tempo prolongado entre o acidente na propriedade e a chegada à clínica contribuiu para a contaminação da ferida. Mesmo com o uso de antibiótico sistêmico e AINE, a deiscência da ferida cirúrgica foi inevitável. 0 uso da pomada à base de papaína a $5 \%$ contribuiu para o controle do exsudato inflamatório infeccioso, que é um dos principais fatores que interferem na cicatrização de feridas, fato este observado ao início do tratamento e que persistiu até a alta do animal. Há indicações do uso do extrato de papaína em diversas concentrações, de acordo com a fase do processo cicatricial e características da lesão. A escolha da concentração da pomada a 5\% deu-se em razão da presença de exsudato purulento e ausência de tecido de granulação. Sua conservação em geladeira diminui os riscos de deterioração e instabilidade da enzima. 0 processo cicatricial sofreu grande avanço após o início da fitoterapia, contribuindo para manter a estética da região peitoral do paciente tratado, sem a observação de efeitos colaterais. $\mathrm{O}$ uso de pomadas manipuladas à base do extrato vegetal da papaína torna-se uma alternativa viável para a cicatrização de feridas cutâneas em equinos, principalmente as que se mostram contaminadas. Esta alternativa diminui o tempo de internação e, consequentemente, os custos relacionados ao tratamento.

Palavras-chave: Carica papaya. Cavalo. Ferimento.

Agradecimentos: Villa Cavalcare, Drogavet. 